\title{
A New, Mushroom-shaped Budding Bacterium
}

\author{
By R. WHITTENBURY AND JUDITH M. NICOLL \\ Department of Microbiology, School of Agriculture, University of Edinburgh, \\ West Mains Road, Edinburgh, EH9 $3 J G$
}

(Accepted for publication 9 March 1971)

A mushroom-shaped budding bacterium, isolated from fresh pond water, is unlike any previously described aquatic budding bacteria (Whittenbury \& McLee, I967; Hirsch \& Rheinheimer, 1968; Staley, 1968). Its morphological 'life-cycle' and other properties are described.

\section{METHODS}

Media. The organism was grown routinely in glucose-salts medium ( $\mathrm{pH} \mathrm{6.9)}$ of the following composition: $\left(\mathrm{NH}_{4}\right)_{2} \mathrm{SO}_{4}, 0 . \mathrm{I} \%(\mathrm{w} / \mathrm{v}) ; \mathrm{NaCl}, 0.05 \%(\mathrm{w} / \mathrm{v}) ; \mathrm{MgSO}_{4}, 7 \mathrm{H}_{2} \mathrm{O}, 0.05 \%$ $(\mathrm{w} / \mathrm{v}) ; \mathrm{NaH}_{2} \mathrm{PO}_{4}, \mathrm{I}_{2} \mathrm{H}_{2} \mathrm{O}, 0.07 \%(\mathrm{w} / \mathrm{v}) ; \mathrm{NaH}_{2} \mathrm{PO}_{4}, 2 \mathrm{H}_{2} \mathrm{O}, 0.03 \%(\mathrm{w} / \mathrm{v}) ;$ glucose, $0.5 \%$ $(\mathrm{w} / \mathrm{v})$, agar (Davis), if required, $\mathrm{I} \cdot 5 \%(\mathrm{w} / \mathrm{v})$ or $0.3 \%(\mathrm{w} / \mathrm{v})$; trace-element solution (Pfennig, $1962), 0.05 \%(\mathrm{v} / \mathrm{v})$; and glass-distilled water. Nutrient agar and yeast extract agar (Difco), $0.5 \%(\mathrm{w} / \mathrm{v})$, were occasionally used.

Substrate utilization. Ability to use a variety of combined carbon and energy sources, aerobically and anaerobically, was tested using a soft agar salts medium (glucose-salts medium without glucose) containing $0.004 \%$ bromothymol blue distributed in $\frac{1}{2}$ in. test tubes. Substrates $(0.5 \%, \mathrm{w} / \mathrm{v}$, final concentration) were filter-sterilized before adding to melted, autoclaved medium. Tubed medium was melted, cooled to $35^{\circ}$, inoculated with a drop of $24 \mathrm{~h}$. culture, swirled to distribute inoculum and allowed to set.

Slide culture. Molten agar medium, generally glucose-salts agar, was poured on sterile glass slides and a sterile cover-slip was dropped immediately onto the surface of the medium to cast a flat surface. After the medium solidified, the coverslip was removed and the agar surface allowed to dry partially before being inoculated from a $24 \mathrm{~h}$. culture. A trough was cut in the agar and a cover-slip placed over the inoculated surface with the trough (air supply) lying centrally under the coverslip. The edges of the coverslip, cleared of excess agar, were sealed with a paraffin wax-petroleum jelly mixture, to prevent drying out. Growth was observed under phase contrast over $24 \mathrm{~h}$. at $30^{\circ}$.

Electron microscopy was as described by Davies \& Whittenbury (1970).

\section{RESULTS AND DISCUSSION}

Physiological properties. The organism was a capsulated Gram-negative, non-spore forming, non-photosynthetic, strictly aerobic heterotroph. Nitrate was not reduced, catalase and oxidase activities were detected; $a$-, $b$ - and $c$-type cytochromes were identified in suspensions of the organism scanned in a Unicam SP80o ultraviolet spectrophotometer. Organic growth factors were not required. Glucose, D- and L-arabinose, galactose, fructose, mannitol, glycerol, sodium gluconate, formate, acetate, propionate, lactate, fumarate, succinate, citrate or glutarate were utilized as combined carbon and energy sources. Acid was produced from sugars and sugar alcohols. Mannose, lactose, maltose, sucrose, dulcitol, 

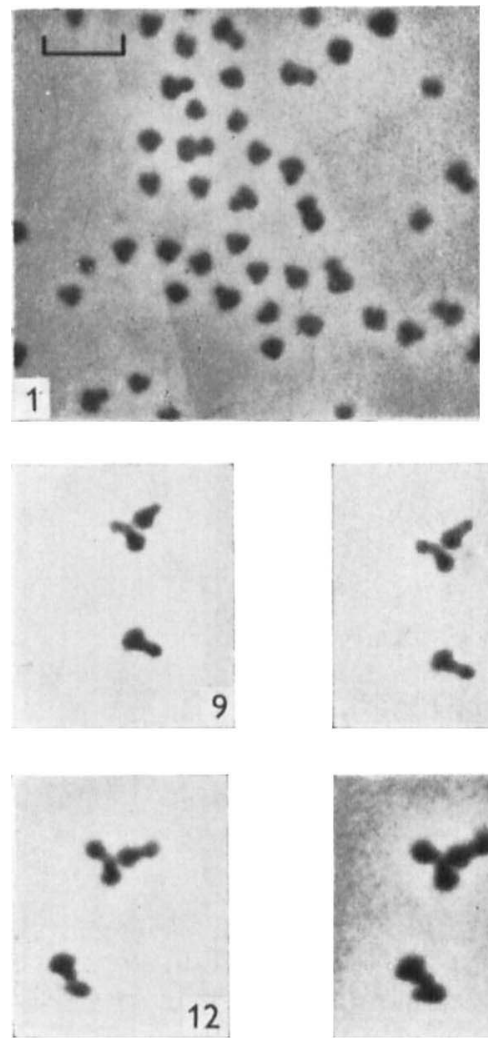

12

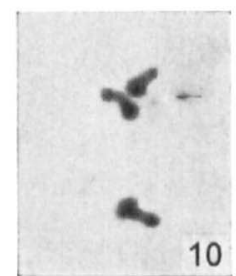

10

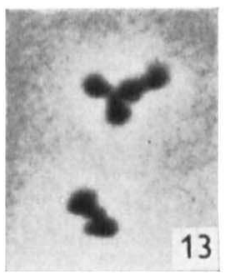

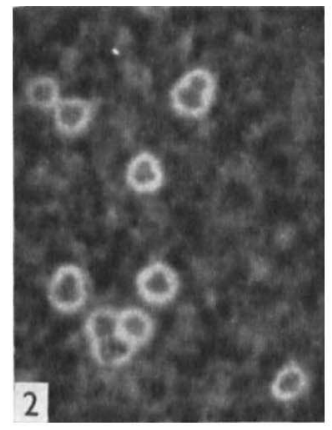
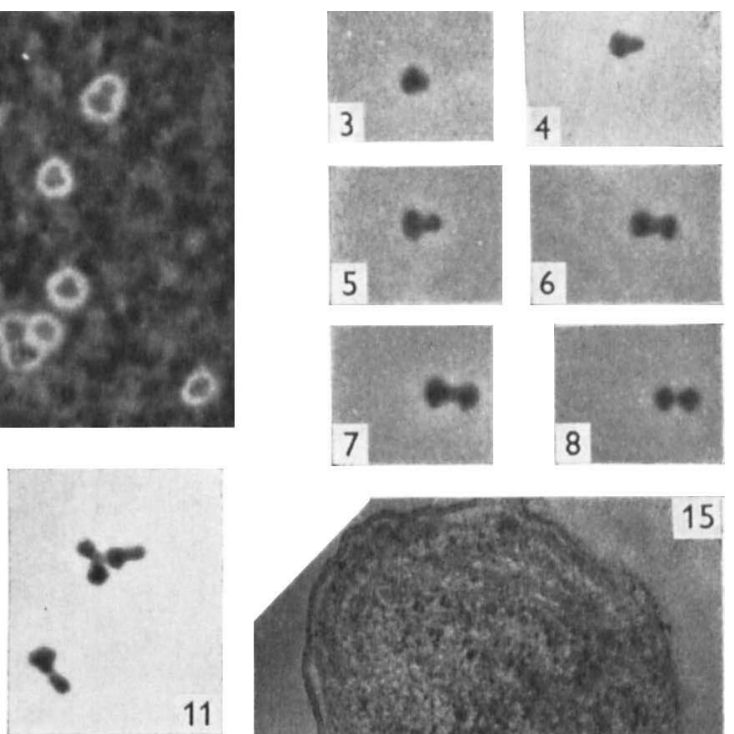

11
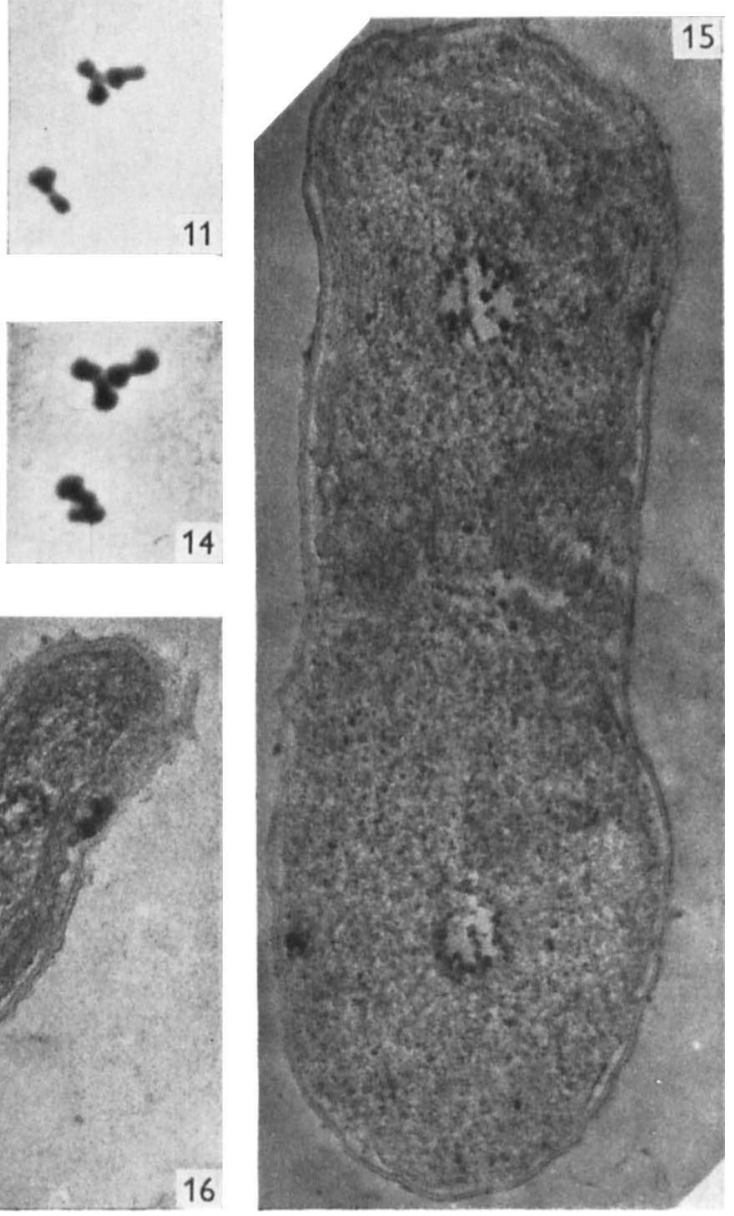

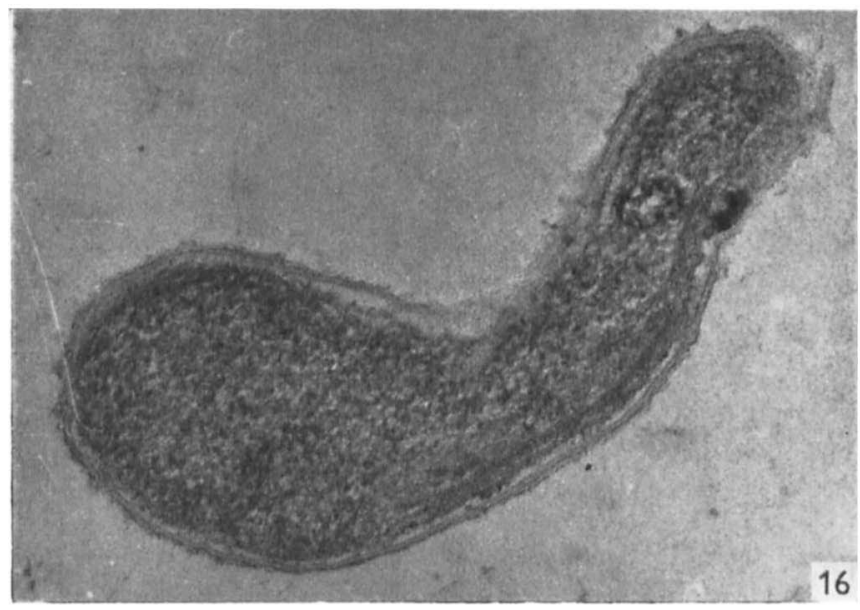

Fig. I to I4 were phase-contrast micrographs. $\times 1900$. The bar (fig. I) equals $5 \mu \mathrm{m}$.

Fig. I. Preparation showing variety of shapes of bacterium.

Fig. 2. Indian-ink preparation showing capsules.

Fig. 3 to 8 . Stages in morphogenesis leading to division.

Fig. 9 to I4. The same preparation (slide culture) at different times over a $3 \mathrm{~h}$. period at $30^{\circ}$.

Fig. 15. Thin section showing membrane in addition to cytoplasmic membrane. $\times 60,000$.

Fig. 16. Thin section showing two membrane accumulations (mesosomes?) in tube of organism at site of cell division. 
sodium butyrate or DL-tartrate, urea, L-glycine, methanol, and hydrogen in the presence of carbon dioxide were not used. Growth also occurred on nutrient agar and on yeast extract agar; on the latter vast amounts of slime were formed. Preliminary analyses of this slime for sugars and amino sugars revealed only mannose. Growth occurred at $15^{\circ}$ but not above $40^{\circ}$; the optimal growth rate was at $30^{\circ}$, at which temperature it grew between $\mathrm{pH} 5.2$ and $8 \cdot 0$.

Reproduction. A microscopic preparation (PI. I, fig. I, 2) showed a variety of oddly shaped organisms, suggesting an unusual mode of reproduction. Slide cultures at $30^{\circ}$ revealed that multiplication was by a budding process (Pl. I, fig. 3 to I4), the generation time being approximately $3 \mathrm{~h}$. The newly divided organisms were mushroom-shaped (Pl. I, fig. 3). Growth began with a doubling in length of the tubed part of the organism; the end section of the tube then began to enlarge, eventually reaching the dimensions of the original, non-tubed part of the mother. At this stage of development the organism was dumbbell-shaped (Pl. I, fig. 7). Symmetric division by binary constrictive fission of the tube soon followed, resulting in the formation of two mushroom-shaped organisms of identical size and shape.

Although this budding process is analogous to that described for other tubed, budding bacteria (e.g. Whittenbury \& McLee, 1967) it differs in one respect. All other asymmetric budding bacteria which form daughter cells at the end of a tube divide asymmetrically; the original, or mother, organism retains the tube and the daughter is tubeless. In other words, the daughter is immature and has to form a tube before commencing to reproduce another organism. In consequence the division time of the daughter lags behind that of the mother by the period required to synthesize a tube. In contrast, this mushroom-shaped bacterium divides into two equivalent organisms which subsequently grow and divide in synchrony.

The mushroom-shaped organism differed morphologically from other tubed budding bacteria in other respects. Phosphate deficiency, which normally induces a significant lengthening of the tube of budding photosynthetic and non-photosynthetic bacteria (N. Pfennig, personal communication; and unpublished results in this laboratory based on the work of Schmidt \& Stanier, 1966, on stalk length in Caulobacter species) did not alter the tube length of the mushroom-shaped bacterium. The only obvious effect of decreasing phosphate concentration was an increase of generation time from $3 \mathrm{~h}$. with $0 . \mathrm{I} \%(\mathrm{w} / \mathrm{v})$ phosphate salts to $10 \mathrm{~h}$. with $0.002 \%$. Unlike other tubed budding bacteria the mushroom-shaped organism was not motile and did not form rosettes.

Fine structure. All budding bacteria known to possess a complex membranous system (Nitrobacter species, Rhodomicrobium vannielii, Rhodopseudomonas palustris, Rhodopseudomonas viridis and Rhodopseudomonas acidophilia) have evolved a pattern of membrane arrangement peculiar to themselves (Whittenbury \& McLee, 1967); lamellae consisting of pairs of membranes are aligned around the circumference of the organism, folding back on themselves and occasionally branching to form an organized unit, attached to the cytoplasmic membrane, several membrane pairs in depth (e.g. Nitrobacter agilis, Murray \& Watson, I965; and Rhodopseudomonas palustris, Tauschel \& Drews, 1967). Although thin sections of the mushroom-shaped bacterium (Pl. I, fig. I6) contained some peripherally aligned membrane in addition to the cytoplasmic membrane, there was too little evidence of organization for us to claim similarity of the internal structure of this organism to that of other budding bacteria.

No sign of cross-wall synthesis was seen at the site of division in any of the sections examined; however, two membranous bodies (mesosomes) (Pl. I, fig. I6) were occasionally observed in the tube at the site of division presumed to be constrictive.

Taxonomy and nomenclature. The organism's physiological properties do not set it apart 
from the numerous non-motile, strictly aerobic Gram-negative bacteria currently being collected into the Acinetobacter-Moraxella complex. Morphologically, however, the organism seems unlike any other previously described. Although it is a budding bacterium its symmetric division sets it apart from other tubed budding bacteria. Consequently, the mushroom-shaped bacterium cannot be satisfactorily classified into any known genus. It is not proposed to erect a genus to accommodate this organism until more is known about it and until similar types have been isolated. A culture, NCMB I785, has been deposited with the National Collection of Marine Bacteria, Torry Research Station, Aberdeen.

We thank Miss Stephanie L. Davies for the electron-microscopy work.

\section{REFERENCES}

DAVIES, S. L. \& Whittenbury, R. (1970). Fine structure of methane and other hydrocarbon-utilizing bacteria. Journal of General Microbiology 6r, 227-232.

HIRSCH, P. \& RHEINHEIMER, G. (I968). Biology of budding bacteria. V. Budding bacteria in aquatic habitats: occurrence, enrichment and isolation. Archiv für Mikrobiologie 62, 289-306.

MurRaY, R. G. E. \& WATSON, S. W. (1965). Structure of Nitrosocystis oceanus and comparison with Nitrosomonas and Nitrobacter. Journal of Bacteriology 89, 1594-1609.

PFENNIG, N.(1962). Beobachtungen über das Schwärmen von Chromatium okenii. Archiv für Mikrobiologie 42, 90-95.

Schmid, J. M. \& Stanier, R. F. (I966). The development of cellular stalks in bacteria. Journal of Cell Biology 28, 423-436.

Staley, J. T. (1968). Prosthecomicrobium and Analomicrobium: new prosthecate freshwater bacteria. Journal of Bacteriology 95, 1921-1942.

TAUSCHEL, W. D. \& DREWS, G. (1967). Thylakoidmorphogenese bei Rhodopseudomonas palustris. Archiv für Mikrobiologie 59, 38I-404.

WhITTENBURY, R. \& MCLeE, A. (1967). Rhodopseudomonas palustris and Rh. viridis - photosynthetic budding bacteria. Archiv für Mikrobiologie 59, 324-334. 